\title{
Moral Judgement as a Method in Historiography: An Analysis of al-Biruni's al-Athar al-Baqiyah 'an al-Qurun al-Khaliyah
}

\author{
MOHAMMAD UMAIR ABD RAHIM \\ *MOHD SYAHMIR ALIAS \\ Philosophy and Civilisation Section, School of Humanities, Universiti Sains Malaysia, \\ 11800 USM, Pulau Pinang, Malaysia \\ *Corresponding author: syahmir@usm.my
}

Published online: 31 May 2021

To cite this article: Mohammad Umair Abd Rahim and Mohd Syahmir Alias. 2021. Moral judgement as a method in historiography: An analysis of al-Biruni's al-Athar al-Baqiyah 'an al-Qurun al-Khaliyah. KEMANUSIAAN the Asian Journal of Humanities 28(1): 127-149. https://doi.org/10.21315/kajh2021.28.1.6

To link to this article: https://doi.org/10.21315/kajh2021.28.1.6

\begin{abstract}
The practice of moral judgement in historiography is a topic in critical philosophy of history. In general, there are two opinions on the practice of moral judgement in history: firstly, those who are against it, such as Croce, Bloch and Butterfield; secondly, those who are in support of it, such as Lord Acton, Ibn Khaldun and al-Biruni. Understanding the practice is crucial in facilitating "intellectual serenity" among historians in deciding on their research method. This article discusses al-Biruni's position and epistemic justification on the issue of moral judgement in research in history. The analysis of al-Biruni's perspective, based on his book, al-Athar al-Baqiyah 'an al-Qurun al-Khaliyah, shows that his epistemic justification on moral judgement in history was influenced by his religious tradition.
\end{abstract}

Keywords and phrases: al-Biruni, moral judgement, philosophy of history, al-Athar al-Baqiyah 'an al-Qurun al-Khaliyah

\section{Introduction}

Moral judgement in historiography is a topic in critical philosophy of history (i.e. philosophy of historiography) (Tucker 2009, 3-4; Vann 2004, 3). According to Vann $(2004,4)$, moral judgement in history is the expression of evaluation on morals of men in the past. Usually in the language of praise or blame. Child (1951, 298) defines moral judgment in history as judgement on motives which prompt the action of his subject matters to be perceived as "good, bad, bold, cowardly, treacherous, stupid and so forth". Oldfield $(1981,260)$ on the other hand describes it as statements that "typically made in language that praises or blames" and "the 
moral character of statements of praise or blame refers to...good and evil". In summary, any historical descriptions that attempt to expose the moral quality or value of any person, institution or party are moral judgements in history. Whenever a historian described historical agent/s with the notion of being better or worse, right, or wrong, it is moral judgement in history (Berkhofer 1995, 142-143; Hooker 2017, 98).

There are two reasons why this article chose to study moral judgement in history from al-Biruni's perspective instead of other topics of his philosophy of history. Firstly, moral judgement in history is a question of method in doing historical research: it is a question of objectivity in history (Vann 2004, 4; Atkinson 1978, 188-189). In other words, discussion over this topic is an effort to establish objectivity in history. In general, there are two opinions on the practice of moral judgement in history: Firstly, those who are against it, such as Ranke, Croce and Butterfield; Secondly, those who are in support of it, such as Lord Acton, Ibn Khaldun and al-Biruni. In light of this, Lord Acton argued, that the judicious exercise of moral judgement by the historian is the guarantee of truth and objectivity (Phillips 2019, 51). As for Ibn Khaldun (1958, 71-72), he argued that "personality criticism" in historiography is a necessary means to identify authentic report. On the contrary, the Rankean historians argue that moral judgement impairs objective historical research (Phillips 2019, 47). Both positions were substantiated intellectually and thus, this topic is an appreciable disputation. Therefore, at the very least, one should not condemn a person just because he/she chose the other position. Rather, encourage intellectual discourse to elucidate which view is closer to the truth.

Secondly, this article is believed to be the first attempt that exposes the epistemic justification for moral judgement in history from the perspective of al-Biruni in his al-Athar. Its importance is supported by the fact that the observed literatures showed research about al-Biruni's philosophy of history with special attention to the issue of moral judgement has yet to be found. The closest writings that do touched upon al-Biruni's moral judgement in history are An Introduction to Islamic Cosmological Doctrines by Seyyed Hossein Nasr (1978) and al-Biruni and the Political History of India by M.S. Khan (1976). Nevertheless, there were abundant of resources which help give insights in studying al-Biruni's philosophy of history; studies which have something to do with al-Biruni's influence, philosophy or ideas in general. Some resources on these include, Brilliant Biruni: A Life Story of Abu Rayhan Mohammad Ibn Ahmad by M. Kamiar (2009) and Al-Biruni: Father of Comparative Religion by Kamar Oniah Kamaruzzaman (2003). 
That being said, intellectual explanation about the practice is believed to facilitate intellectual serenity among researchers in deciding their research method, whether to side with those who are against moral judgement or with those who support it. Either way, this article's finding will give better insights to those who are having the dilemma because it highlighted the views of al-Biruni, who was an authoritative historian to rely upon. This article therefore aims to identify al-Biruni's position on the issue of moral judgement in historical research and the epistemic justification for it.

Given the scarcity of academic studies on al-Biruni's philosophy of history, specifically on moral judgement in history, this article devises two approaches to inquire about al-Biruni's position and its epistemic justification. First, al-Biruni's stance with regards to the propriety of moral judgement in history. Secondly, what the academics have said regarding moral judgement in history and correlates it with al-Biruni's practice of moral judgement. The first part will be acquired via analysis of al-Biruni's historical work, al-Athar al-Baqiyah. For the second part, it will be used in elucidating the epistemic justification of al-Biruni's position. This is because, al-Biruni was not found to specifically dedicated a work in philosophy of history. Khan $(1976,86)$ stated that "al-Biruni has not discussed his idea of history specifically in any of his works; but glimpses into this aspect of his thought may be obtained from his introductions to the two important works...", referring to al-Biruni's al-Athar and Tahqiq. Thus, external philosophical analysis especially epistemological explanation will be presented in this article. Therefore, this study is qualitative for it utilises library research and content analysis.

\section{Introducing al-Biruni and al-Athar al-Baqiyah}

His name is Abu Raihan Muhammad Ibn Ahmad al-Biruni. Famously known by his nickname, al-Biruni. "Abu Raihan" (father of Raihan) is his kun-yah, a practice of reference which is famously used in the Arabic world (Notzon and Nesom 2005, 20). According to Kamiar $(2009,1)$, the name "Biruni" was given to al-Biruni's family by the native village of Vasemereed which in Persian means "outsiders" because al-Biruni's family had migrated from the city of Khwarizm to the village. "Biruni" is a laqab, a descriptive epithet which is, again, traditionally used by the Arabs (Notzon and Nesom 2005, 20). It is obvious al-Biruni was not an Arab, but a Khwarizmian because he was born in Kath, Khwarizm in 4th September 973 AD (Gafurov 1974, 5; Ahmad 2010, 167; Ardi, Fatimah and al-Tamimi 2016, 2). 
His early academic journey was influenced by his Greek teacher and his own sociocultural circumstances which provided him with academic culture and treasury of knowledge (Ardi, Fatimah and al-Tamimi 2016, 2; Gafurov 1974, 5; Krenkow 1951, 195). The manifestation of his brilliant intellect can be seen from his good command in Persian and Arabic. He was also well-acquainted with Greek, Turkish, Hebrew and Sanskrit although he only authored his works in Arabic and Persian (Nasr 1978, 110; Ahmad 2010, 167; al-Biruni 1879, xii). According to Ahmad (2010, 168), al-Biruni "wrote about 180 books in Arabic and Persian languages, of which few have survived the test of time". Despite having to live through the political upheavals which interrupted his work and witnessed the rise and fall of the two early feudal empires (the Karakhanid and the Ghaznavid) he managed to give outstanding academic contributions; produced many works. But, unlike Ibn Sina, not until the previous century, al-Biruni was unpopular except among academic experts (Gafurov 1974, 4; 6).

Given these compliments, it is worthwhile to highlight al-Biruni in our intellectual discourse. It is interesting to see how a boy, who was once abducted into slavery, taken away from his family, would then became an influential man, an academic expert who served the court of Ghaznavid rulers (Kamiar 2009, 12-15; Gafurov 1974, 8; Kamar Oniah 2003, 114-115). With regards to his religious belief, it can be asserted that he was a Muslim of Sunni (orthodox) tradition. According to Said $(1974,36)$, despite of the age of quarrel between the orthodox schools of thought (madhahib), he "seems to have been a liberal orthodox Muslim who did not find it necessary to condemn the other schools of thought". Although many people claimed that al-Biruni was of Shiite, but the claim does not seem to be grounded with adequate proof (Nasr 1978, 114). This is also supported by al-Biruni's disagreement on some of the Shiite's doctrine, although he did pray for the Shiite zaidiyya's goodness (al-Biruni 1879,$8 ; 79$ ). There were disputes on when al-Biruni passed away. Nonetheless, one thing could be agreed upon is that in 1050, he already passed away in Ghazni (Ahmad 2010, 168; Ardi, Fatimah and al-Tamimi 2016, 2).

Al-Biruni was a polymath, not only was he an expertise in the field of history, but also many other disciplines including science, mathematics, geography and philosophy. This is evident from his writings on the subjects (Ahmad 2010, 168169). With regards to history, he has produced two works in Arabic: Tahqiq ma li al-Hind min Maqulah Maqbulah fi al- 'Aql aw Mardhulah [Verifying All that the Indians Recount, the Reasonable and the Unreasonable] and al-Athar al-Baqiyah 'an al-Qurun al-Khaliyah [The Chronology of Ancients Nations] (al-Biruni 1910, $1 ; 1879$, ix). It is the purpose of the article to unravel al-Biruni's thought on moral judgement in history in his al-Athar al-Baqiyah. Therefore, it is best to give a 
short introduction on this magnificent work of his. According to Sachau (al-Biruni 1879, viii; ix), al-Athar al-Baqiyah was composed in between $390 \mathrm{AH}$ to $391 \mathrm{AH}$, approximately in $1000 \mathrm{AD}$, earlier than Tahqiq ma li al-Hind which was composed later (408 AH). Al-Athar al-Baqiyah was first published in Russian in the 19th century and it was al-Biruni's first major work which made him to be known as an outstanding historian (Boilot 1974, 12; Gafurov 1974, 4). Al-Athar al-Baqiyah not just a monumental historical work, but also a research dedicated to the court of Qabus ibn Wushmagir Shams al-Ma'ali during his stay at the court for some years (al-Biruni 1879, 1-2; Khan 1951, 171).

Al-Athar al-Baqiyah was composed for two reasons: as a form of formal service and an attempt of fulfilling intellectual responsibility. This is evident from al-Biruni's statement in al-Athar al-Baqiyah:

A learned man once asked me regarding the eras used by different nations and regarding the difference of their roots... further regarding the causes which led to such difference and the famous festivals and commemoration days for certain times and events. He urged me to give an explanation... Besides, I was encouraged by that robe of blessed service, in which I have dressed myself, to compose an explanation for him, who occupies a high throne, that he may see herein a new sign of my service. (al-Biruni 1879, 2-3)

It is thus clear what is the general content and scope of study in al-Athar al-Baqiyah. Al-Athar al-Baqiyah is used as the main source in studying al-Biruni's aspect of philosophy of history because it was regarded by many scholars as his first major historical work and the most popular one besides Tahqiq ma li al-Hind. But, as observed by Nasr $(1974,39)$, al-Biruni has not left behind any independent literature on philosophy, rather his philosophical views were interspersed with his work's main topics and thus, must be carefully extracted.

\section{Moral Judgement in al-Biruni's Historiography}

Before assessing al-Biruni's moral judgement in historiography, it is best to first explain how this analysis is going to be done. Firstly, al-Biruni's view on moral judgement in history will be extrapolated from selected evidence; quotations from al-Athar al-Baqiyah that represents his view will be laid down (e.g. to proof whether he is in support of moral judgement or not). Then, explanation to establish what he really meant from the selected words will be given which subsequently, affirms what is al-Biruni's position with regards to moral judgement in history research. 
Moral judgement in history not only referring to the author's description of certain moral status or value attributed to individual(s) in the past, but also referring to any historical description which denotes certain moral pronouncement on any individual. This is because the description of an author implies intention. Therefore, if an author used words in any context that he or she was trying to explain, the word itself imbued with the author's intention. It is only the matter of really confirming what was the author's intention. In this case, if a historical description involves the use of words which implied moral pronouncement, it is regarded as moral judgement. Even just words such as "cruel", "evil", "good", "noble", "deceitful" and "foolish" are considered as moral judgement (give examples that follishness is also a moral judgement).

Having established that, this study observed that al-Biruni implemented moral judgement in his study; evidence will be given to prove this. Going further, this study identified three main forms of moral judgement used by al-Biruni in his work:

1. Personal moral judgement in describing actor/s in the history being studied.

2. Impersonal moral judgement in describing actor/s in the history being studied.

3. Moral judgement towards the historical sources being studied.

Al-Biruni's use of these forms of moral judgement were also interspersed. Also, these forms of moral judgement were given by al-Biruni both explicitly and implicitly.

\section{Personal moral judgement in describing actor/s in history}

In al-Athar, al-Biruni was often found describing historical agent/s as having certain moral attribute and quality where the judgement came from himself. For instance, in assessing the authenticity of a copy of Bible used by Christians, al-Biruni implored moral judgement unto the king Ptolemaeus Philadelphus as coercively causes the Jews to mistranslate the torah. He depicted the king to be "violence" and doing "maltreatment" to the Jews (al-Biruni 1879, 24). In this example, the use of describing the moral quality of the king was also a means to explain the historical sources. Hence, the two forms of moral judgement were interspersed.

In showing the difference between invented genealogy and true one, Al-Biruni $(1879,47)$ gives example of some uncontested pedigree which also includes his benefactor's. In doing that, he praises his benefactor, "the glorious and victorious, 
the benefactor, shams-al-ma'ali... not one of his friends, whom may God help, nor any of his opponents, whom may God desert, denies his noble and ancient descent". In this light, he can just state his benefactor's pedigree without giving such personal praises. But we can understand that it is due to his respect and formal salutation because al-Athar was also written upon his benefactor's request.

Additionally, this form of moral judgement can be seen in al-Biruni's criticism on the computation of Abu Ma'shar al-Balkhi (a secondary historical source) on the era of "the great flood". He said, "This man, who is so proud of his ingenuity, had computed these star-cycles only from the motion of the stars... The discrepancy of the cycle... is a sufficient argument for...repudiating the follies commited by Abu Ma'shar and relied upon by foolish people." (al-Biruni 1879, 29; 31). Clearly, this is a moral judgement from al-Biruni because he can simply say that the account was wrong and give evidence for it without denoting the word "ingenuity" or "follies", yet he still includes the additional moral descriptions. Therefore, this moral judgement was his own brilliant evaluation.

Al-Biruni's personal moral judgement towards historical agent/s may be descriptive and non-descriptive. Descriptive and non-descriptive here means, the judgement either informs readers about the judged person by name and detail or anonymous. The latter can be found when al-Biruni expresses moral judgement to some people without mentioning their names: "Someone among the inexperienced and foolish people of the Hashwiyya and Dahriyya sects, have rejected as incredible the long duration of life which has been ascribed to certain tribes in past, specially to the patriarchs before the time of Abraham" (al-Biruni 1879, 90). The given description clearly shows that al-Biruni condemned "some people" from the two sects. An example of the descriptive moral judgement is when al-Biruni wrote, "Other people, besides, hold this foolish persuasion, viz. that time has no terminus a quo at all...you could hardly find a prettier tale of this kind than that one produced by Sa'id ben Muhammad aldhuhli in his book" (al-Biruni 1879, 116).

\section{Impersonal moral judgement in describing actor/s in history}

This form of moral judgement refers to a judgement not directly from al-Biruni's evaluation. In other words, the judgement came from others, yet it informs readers the moral quality of the historical agent/s. For example, when al-Biruni was applying comparative technique in positing moral quality, "the Maniccheans have a gospel of their own...but the Maniccheans...believe that it is the correct gospel, that every gospel is false and its followers are liars against Messiah" $(1879,27)$. This is impersonal because al-Biruni gave that moral description not from his own judgement, rather pointed out that others view the mainstream Christians as "liars", 
which indirectly pronouncing their moral quality. Now, why did al-Biruni gave the impersonal description of moral judgement? There must be intention behind it. If observed, it was definitely to notice the readers that there were disputes over the historical accuracy of the mainstream Christian's gospel, by one of their own sects. This is the inference which best explained why al-Biruni inserted the Manicchean's contention.

Another example for his use of impersonal moral judgement is when al-Biruni uses tradition that are instilled with moral judgement, "People say, that the son of Wardansyah obeyed the orders of Asfar ben Shirawaihi and that it was he, who suggested...the idea of delivering the people from the tyranny and oppression of Asfar" (al-Biruni 1879, 47). Al-Biruni's impersonal moral judgement is necessary for certain purpose. One of the purposes was to explain the system of eras of the ancient nations. For example, he stated that the Khwarizmian at some times "imitated the example of the Persians in dating by the years of the reign of each king of the line of kaikhusru...this went on down to the reign of Afghir... His name was considered a bad omen like that of the Yazdajird the Wicked, with the Persians" (al-Biruni 1879, 41). The impersonal moral judgement which states "Yazdajird the Wicked" was presented by al-Biruni for this purpose.

\section{Moral judgement towards historical sources}

Historical sources are the evidence in any form which made up a historical narrative. If categorised from its level, it can be divided into two: (1) primary source and (2) secondary source. Most of the time, historical sources are in the form of testimony (written or oral) (Morgan and Rasinski 2012, 584; 588; Barton $2005,750-751$ ). Putting aside valid reasoning which is based on first principle as a necessary source, archaeological findings are also historical source. Archaeological source, however, does not have personality and is amoral (Collingwood 1966, 238-239; Kosso 2006, 8). Therefore, moral judgement towards historical source refers to judgement on testimonial source only, not archaeological source. Having said that, al-Biruni was found giving moral judgement towards historical sources in many places in al-Athar. The rationale and purpose of his practice of moral judgement towards historical sources will be given subsequently after selected evidence was laid down. 
Al-Biruni $(1879,23)$ said:

All they have brought forward and all we are going to propound, is a decisive proof and a clear argument, showing that the words in their holy books have been altered from their proper meanings and that the text has undergone modifications contrary to its original condition. Having recourse to this sort of computing and of using false witness, shows and proves to evidence, that their authors purposely deviate from the path of truth and righteousness.

Subsequently, he quoted Surah al-Hijr (15:15) which indicates that it has to do with their spiritual problem; they are being stubborn and blindfolded themselves.

This shows that al-Biruni was depicting the author of the historical sources (in this case, the biblical texts) as morally wrong, when he can just simply state the incorrectness of the biblical information without accessing and exposing the personality of the authors to the public. Also, this proves that al-Biruni was adopting moral assessment in confirming the testimonies of the Christian and Jewish historians. This is also supported by the fact that al-Biruni attempts to give reasons for why some of the Christian chroniclers still clinging to their error and devise things which were not acknowledged by men in general. In other words, he "delved into the personal" and through it, he concluded that it was because of stubbornness in accepting the biblical prophecy of Prophet Muhammad (al-Biruni $1879,22-23)$. This clearly shows al-Biruni asserted moral judgement towards historical sources. In this example, his moral judgement was meant to explain the contradiction of interpretation done by the Jewish and Christians historian regarding the biblical version of the era of creation (al-Biruni 1879, 18-19). This is an example of his moral judgement towards primary historical source; the authors of the Bible.

In light of this, Lord Acton also acknowledged the importance of moral judgement towards historical sources. As in his Inaugural Lecture, Lord Acton $(1911,42)$ said:

Historian has to be treated as a witness and not believed until his sincerity is established. The maxim that a man must be presumed to be innocent until his guilt is proved, was not made for him. For us then, the estimate of authorities, the weighing of testimony, is more meritorious than the potential discovery of new matter.

Meaning, prior to verify the content of a report, even from historians, verify the reporter's trustworthiness first. Otherwise it becomes really difficult to discern the truth in the report. 
Other example of al-Biruni's moral judgement towards historical sources is when he said regarding Ahmad b. Muhammad b. Shihab, a leader of Haruriyah missionaries:

This same trickster of a missionary relates that this table was the work of Ja'far b. Muhammad Alsadik at the time... This malefactor has invented tales about that wise lord, the noblest of the nobles, the wisest of the imams...by making him responsible for something that is inconsistent with the religion of his ancestor (i.e. Ali). (al-Biruni 1879, 182-183)

Al-Biruni's harsh commentary on the leader of Haruriyah, i.e. Khawarij was because he claimed Ja' afar al-Sadik to be providing information about the practice of fasting that does not suit with what the mainstream Muslims maintained (al-Biruni 1879, 183). This goes to show that moral judgement towards historical source was assessed through comparison between authorities' moral status. In this light, Ja'afar al-Sadik, a source in Islamic history was conferred by the majority of Muslim scholars as a pious historical figure (Bufano 2008, 140; 143). Thus, when the moral merit between Ja'afar al-Sadik and Ahmad b. Muhammad b. Shihab were weighed up, it is plausible to believe that Ahmad b. Muhammad b. Shihab (a devout khawarij) has attributed Ja'afar al-Sadik something which Ja'afar did not do or speak.

\section{Al-Biruni's justification for moral judgement in his al-Athar al-Baqiyah}

Al-Biruni believes that practice of moral judgement in history does not necessarily impair objectivity. In light of this, Sachau wrote that al-Biruni "seems to have been a truth-loving man, attacking all kinds of shams with bitter sarcasms" (al-Biruni 1879 , xiii). Notwithstanding, some may contend that al-Biruni's purpose of writing al-Athar because the ruler asked him to is a liability towards his objectivity. In other words, because al-Athar was composed for the ruler, therefore it is bias. This is also strengthened by the fact that al-Biruni praises Qabus ibn Wushmagir Shams al-Ma'ali in such a high position.

This conclusion is untrue because of the following. Firstly, al-Biruni wrote al-Athar as an intellectual endeavour and formal service because the ruler himself was a "learned men" (al-Biruni 1879, 2). Qabus (the ruler) merely asked al-Biruni to write a book because he wanted to know further about the subject. It has nothing to do with bias or partiality, rather a service to knowledge. Therefore, it is the aim of al-Biruni to present al-Athar as an objective, unbiased historical writing. This is why, he says that "it is our duty...to gather the traditions from those who have 
reported them, to correct them as much as possible and to leave the rest as it is, in order to make our work help him, who seeks truth and love wisdom" (al-Biruni $1879,4)$. It is clear that the objective of al-Biruni was for "truth" and because the "learned men", Qabus, was a truth-seeker.

Secondly, the assumption that only Qabus ibn Wushmagir was given such high praises is an unappreciation of al-Biruni's act of dedication, respect and fair judgement. Actually al-Biruni $(1879,46)$ asserted the Prophet (pbuh) in a higher position which is, "the lord of mankind". This is also attested by the fact that he quote the Holy Quran attestation that the Prophet (pbuh) was the greatest men to be followed (al-Biruni 1879, 2). The Qur'anic praise towards a person is more than sufficient to outgrow any praises given by human. In fact, al-Biruni addressed the descendant of the Prophet (pbuh) as "the noblest of the nobles" (al-Biruni 1879, 183). All of these are clear signs of higher praises given by al-Biruni to other othan Qabus ibn Wushmagir.

Thirdly and an important overlooked aspect was the act of dedication of al-Biruni. It must be appreciated that al-Biruni was a man of etiquette and his work, al-Athar, was meant to provide knowledge for a ruler (amir). Therefore, it is only ethically correct if he would give praise and salutation to him as in other formal service presented to a ruler (al-Biruni 1879, 1-2; 131). Hence, to deny al-Athar as bogus or bias just because al-Biruni included his gratitude and dedication to his benefactor, Qabus, was actually a baseless action unbacked by any intellectual inquiry. Moreover, there are more prove to show that his writing was meant to be objective than intentionally bias.

In fact, the praises that he gave towards his benefactor is nothing short of a fair judgement and supplication of goodness (see al-Biruni 1879, 1-2; 47). This can be seen when al-Biruni $(1879,131)$ writes:

Some of them, however, have gone beyond this limit, calling themselves Amir al-a'lam and Sayyid al-umara. May God inflict in them ignominy in this world and show to them and others their weakness! ... As to the Amir, the glorious prince, may God give a long duration to his reign! (to whom this book is dedicated)... He, therefore selected for himself a title...which did not exceed his merits... the khalifs... want to redouble and to increase his title, but his noble mind declined it.

Al-Biruni also states no more than the truth regarding the nobility of Qabus' ancestors (see al-Biruni 1879, 47). 
It is normal to show our appreciation and gratitude when presenting our intellectual writing requested by our king. Also, there is no necessary logical connection between al-Biruni's praise towards Qabus, his ruler and bias in al-Athar. What is the interest of al-Biruni's explanation about the era of ancient nations to Qabus? As far as the work observed, there is none except to gain increase in knowledge about the subject. Furthermore, the title Shams-al-Ma'ali (Sun of the Heights) was not given by al-Biruni, rather by the Abbasid Caliph of the time (al-Biruni 1879, 129-131; 367). Therefore, it is only fair to say that al-Biruni's al-Athar was written without any intentional bias, unless evidence can be produced to prove otherwise.

Al-Biruni makes moral judgement in his work to ensure objectivity. He believes that it is important to do moral assessment and uses authority that pronounces moral judgement on historical agent/s in order to "show how partial people are to those whom they dislike and how hostile towards those whom they hate, so that frequently their exaggeration in either direction leads to the discovery of their infamous designs" (al-Biruni 1879, 38). His statement "their infamous designs" was loaded with moral judgement. In other words, moral judgement had to be done to expose lies residing in the sources; to discern the truth and falsehood. As he himself states after rebuking a fasting tradition of a deviant sect, "God grant that we may always belong to those who follow and further the truth, who crush and expose that which is false and wrong!" (al-Biruni 1879, 81).

Al-Biruni gives moral judgement not only to reconstruct true historical information, but also to clear slanders and lies being attributed to historical agent/s. This can be seen in the previous example where al-Biruni condemned Ahmad b. Muhammad b. Shihab for attributing lies on Ja'afar al-Sadik (al-Biruni 1879, 182-183). Another example is when al-Biruni wants to clear the slanders made by Syncellus towards Prophet Abraham that the prophet sacrificed his son to planet Saturn because he regretted destroying the idols. Al-Biruni $(1879,186-$ 187) said, "Ibn Sankila (Syncellus), the Christian, relates in his book which he, stuffed with lies and futile stories". Al-Biruni then refutes Syncellus' distortion with clear evidence. This method of moral judgement in history is also practiced by Ibn Khaldun $(1958,28-29)$ where he refutes the slander towards al-Abbasah, al-Rashid sister, that al-Rashid allowed his sister to be consummated without marriage with his client: "This story is irreconcilable with al-Abbasah's position, her religiousness, her parentage... Where should one look for chastity and modesty, if she did not possess them?". In light of this, Lord Acton also argue that moral judgement is required to present a true moral conception on a past events (Babbage 1964, 32-33). 
Al-Biruni also views that it is necessary to identify and expose the moral status of historical sources and actors in order to unravel the reality of historical events and its sources. This can be further understood when al-Biruni was explaining the various opinions and claims about the figure Dhu al-Karnain and Alexander al-Yunani:

Enemies are always eager to revile the parentage of people, to detract from their reputation and to attack their deeds and merits, in the same way as friends and partisans are eager to embellish that which is ugly, to cover up the weak parts, to proclaim publicly that which is noble and to refer everything to great virtues. (al-Biruni 1879,44 )

Consequently, this showed his awareness about the use and abuse of moral judgement in history. In this light, we could argue that al-Biruni's method is the "proper" moral judgement. What was meant by "proper" moral judgement is a moral judgement conducted not of ill-intention, but of doing service for moral truth and being careful not to accept false stories as truth. In order to manifest this, it is therefore necessary to practice moral judgement in history to combat blameworthy moral judgement. The way to practice proper moral judgement according to al-Biruni, we must abstain from extreme kind of benevolence or improper hatred and obstinacy because it "leads people to invent laudatory stories and to forge genealogies which go back to glorious ancestors" (al-Biruni 1879, 45). These also proved that al-Biruni assessed the moral conduct of the reporters or sources and make judgement upon its authenticity.

Moral judgement of al-Biruni does not mean he was partial (bias), in fact it was to combat bias. Proof for this is when he said about his studies of the Christian and Jewish tradition, "Now, since it has been our object hitherto to point out scientific truth... In all of which we are guided by the wish that both parties should dismiss from their minds the suspicion that we are partial to any side or try to mystify them" (al-Biruni 1879, 319). As paradox as it seems at first glance, al-Biruni saw that practicing moral judgement properly is important to know the biases of someone and the truthfulness of moral judgement applied by the sources. This can be seen in al-Biruni's commentary about al-Jabali (a secondary historical source):

Must have been enmities and grudges between him and the Persians. For he is not satisfied at exalting the Arabs at the expense of the Persians, but he must needs make the Persian the meanest, vilest and most degraded of all nations, attribute to them even more. (al-Biruni 1879, 227) 
Al-Biruni's concern over the needs to distinguish between proper moral judgement and the improper one can be seen from this statement of his: "for the knowledge of the proper mean between disparagement and exaggeration and the necessity of the greatest carefulness for everybody who wants to give a fair judgement" (al-Biruni 1879, 46). His fair judgement can also be seen when he tread lightly in giving one. For example, when he said regarding Mazhdak's ben Hammadan, the pseudo-prophet: "According to others, again, this Mazhdak was a cunning sort of man, who managed to concoct a system" (al-Biruni 1879, 192). He carefully uses the word "according to others" to signal that the moral judgement given was not securely confirmed to be true and subsequently, transfer the responsibility to the source.

Notwithstanding, if we look throughout al-Athar al-Baqiyah wholly, we will find that in many instances al-Biruni criticised something (e.g. ideas) with no moral notion in it; he just criticised the truth of the knowledge derived and gave his own explanation without criticising the personality of the historical agent/s and sources (see for example, al-Biruni 1879, 97; 174). Therefore, it follows that there must be some "reasons" for al-Biruni to make moral judgement and some of them have been explained along with the evidences provided.

\section{Al-Biruni's religious influence in making moral judgement}

Nasr $(1974,38-39)$ observed that al-Biruni's method in doing research in general was influenced by Islamic doctrines and traditions. Even al-Biruni's position in practicing moral judgement in history (to what extent it is allowed and prohibited) was influenced quite heavily by Islamic tradition. The justification that this was his stance can be seen when al-Biruni used al-Quran not only as authoritative source, but also applying its teachings. For instance, when he said about Dhu al-Qarnayn, "the story about him as contained in the Koran, is well known and intelligible to everybody who reads the verses specially devoted to his history...that he was a good and powerful man, whom God had gifted with extraordinary authority and power" (al-Biruni 1879, 43). This implies that al-Biruni accepted al-Quran as historical source, viewing Quranic explanation as appealing to reason and subsequently indicates that he accepted the use of moral judgement in historical description because al-Quran justified the practice.

Not only that, al-Biruni was also influenced by 'ulum al-hadith (sciences of narration) in doing his historical research. This is evident when he displayed his trust and preference on the accuracy of traditions via hadith method over traditions which went through other methods. He says, "If they contend (abovementioned) tradition, which is traced back to Muhammad himself...we must 
say that such an interpretation is unfounded" (al-Biruni 1879, 78). This showed that al-Biruni refutes other sources which contradicts what the hadith has said. Besides, it explained why al-Biruni adopt the practice of moral judgement in historiography because 'ulum al-hadith is basically, in a sense, a science which exposes the moral value or moral status of the past actors and historical sources (Falola 2011, 602; Fischel 1961, 109-110; Brown 2009, 259).

In fact, al-Biruni displayed quite knowledgeable about 'ulum al-hadith itself; he was a meticulous observant over hadith traditions (Nasr 1978, 112). He knows that hadith must not be accepted solely just because it is hadith. For instance, he brought the story of how hadiths were fabricated; the confession of Abd al-Karim ibn Abi al-Awja after he (Ibn Abi al-Awja) was certain that he is going to be beheaded: "By God, now that you are going to kill me, I tell you that I have put down 4,000 traditions (in my books), in which I forbid that which is allowed and allow that which is forbidden". Then, al-Biruni unambiguously addressed this man as heretic which is a morally negative connotation (al-Biruni 1879, 80).

Not peculiar to al-Biruni, Ibn Khaldun also was heavily influenced by Islamic teachings that led him to unambiguously apply the canons of morality towards historical agent/s, be it actors in history or sources. Ibn Khaldun employs the method of ulumul hadith in his writing, as Rosenthal notes, "this was in keeping with traditional Muslim biographical practice...for exact data concerning their authorities" (Ibn Khaldun 1958, xxxviii). This is evident in many places of his Muqaddimah. For instance, to expose the falsehood in a report, Ibn Khaldun $(1958,10)$ criticised (jarh) a narrator, Ibn Rashiq in Mizan al-A 'mal and the "lost sheep" who followed him as follows, "No credence can be given to what they say. They are not considered trustworthy...". Also, Ibn Khaldun (1958, 37-38) uses 'ulum al-hadith to refute the report that accused Ibn Akhtam and al-Ma'mun drinking wine together, "Yahya b. Akhtam was a transmitter of traditions. He was praised by Ibn Hanbal... At-Tirmidhi published traditions on his authority... To vilify Yahya is to vilify all of these scholars". He then praises Yahya to explain the false report, "for he was much envied because of his perfection". Hence, it is visible that Ibn Khaldun, similar to al-Biruni, employ praise and blame in his historiography because of religious influence.

\section{Philosophical Analysis on the Epistemic Justification of al-Biruni's Moral Judgement in History}

In this section, philosophical and epistemic justification for al-Biruni's moral judgement will be given by means of analysing his views from external authority (other scholars). Epistemic justification basically referring to the justification 
towards the means of acquiring knowledge. It means that the proposition of a person has positive epistemic status for him or her. If someone - for example believed that the roundness of the earth to be certain and an unchangeable fact, meaning that he had acquired this knowledge (belief) through some sort of means; it may be through observation, testimony, logical reasoning, etc. Not only epistemic justification wants to identify what means were used to arrive at a knowledge, but more importantly, it tries to understand or demonstrate why is the case that the means used are eligible in constituting knowledge and if it does, what "positive epistemic status" does it hold? Can it be certain, approximately certain, positive, etc.? (Plantinga 1986, 3).

This study verified the following al-Biruni's proposition: "Proper moral judgement must be practiced in history research". Having said that, the epistemic justification for this can be understood from the following questions: Why is moral judgement must be delivered in finding the truth of historical knowledge (past events)? What are the effects towards the epistemic status of history if moral judgement were not allowed in doing historical research? Now, what is of difficulty here is when philosopher distinguishes true belief from knowledge. True belief is a part of knowledge, but not knowledge itself because someone may also have false belief which was constituted via knowledge he acquired (Plantinga 1986, 3-4). Not going deeper into this, we refer the epistemic justification of al-Biruni's moral judgement to be the justification for knowledge of true belief. In the justification of al-Biruni's moral judgement, two arguments will be laid down below.

\section{Freedom of expression as the grounding for moral judgement in history}

The discussion about moral judgement, moral connotation and expression must be brought into its basic philosophy. First and foremost, the very fact to deliver any judgement or expression falls under the philosophical discussion of freedom of expression. Now, what is freedom of expression? How free is it? We argue that the reason for why men had struggled to attain freedom of expression is because there are some objectives to be achieved from it. Considering this, Shaw (2012, $29)$ and Mill $(2001,19)$ postulated that the fundamental objectives to have freedom of expression is for (1) accountability, (2) truth and (3) progress. Applying these principles, it leads to the conclusion that proper moral judgement in history research is permissible. If the moral judgement or expression in historical narratives were given to elucidate "truth" of past event, for example, then it is obviously allowed or even encouraged. In this light, al-Biruni's practice of moral judgement includes the purpose of establishing truth, progress and accountability. This will be further demonstrated. As previously discussed, al-Biruni uses moral judgement in order to ascertain the authenticity and credibility of the historical sources he used. 
Examining al-Biruni's moral judgement towards past's agents in his al-Athar al-Baqiyah, it is plausible to conclude that his judgement is under the scope of accountability, truth and progression. For accountability, there were many instances that al-Biruni in al-Athar al-Baqiyah had delivered moral judgement for the purpose to make the liar and deceiver be accountable for their deeds and actions; evidence for this has been explained above (see also al-Biruni 1879, 182-183). An example of a moral judgement which is not efficient for accountability is, say a prosecutor wants Adolf Hitler to be "accountable" for killing six million Jews. Instead of giving historical evidence of what Hitler did previously to substantiate that he was a bad (blameworthy) person, the prosecutor insults Hitler's ancestors. The insult, which was a moral judgement is irrelevant to be taken by the judge in order to pass judgement over Hitler. Example which shows that al-Biruni was not implementing this "improper moral judgement" can be seen when he criticised al-Jabali (a secondary historical source) (see al-Biruni 1879, 227).

As for progress, in history research the principle of "progress" correlates with "truth" because the very purpose of history is it serves as lesson and reminder (Collingwood 1966, 10; Boucher 1985, 8). Lesson implies learning, which implies progression. As Voltaire viewed it, to study history is to receive lesson in order to progress (Sakmann 1971, 44). From this perspective, lesson goes hand in hand with truth; if an information was known to be a forgery (false), why bother taking lessons from it? To further understand the principle of progress and truth for every judgement, consider the following: if one were to ask a certain group of people to know the "truth" of their tradition by practicing the "freedom" to insults, it would not be an efficient way to achieve the objective (truth about that tradition). Similarly, if a physician were to teach physics by slandering certain religious tradition which offended some students, the slander certainly was not an efficient way towards "progression" of learning physics. Therefore, if al-Biruni's al-Athar al-Baqiyah was to establish the objective truth of a past event (al-Biruni 1879, $81 ; 338)$, it follows that what it offers is history proper, which contains lesson for men to progress. The proof that al-Biruni delivers moral judgement in the context of articulating truth and progress can be found in many statements of his (see the previous sub-topics). For example, he mentioned that his endeavour is pointing out "scientific truth" about the Jewish and Christian traditions with the hope that they do not saw him to be depicting their traditions nastily (al-Biruni 1879, 319).

\section{If Islamic preservation of history is valid, al-Biruni's moral judgement is valid}

Before going further to the argument, one must know that assessing the authenticity and credibility of historical sources does not only mean to evaluate the strength 
of its preservation, memory and the source's expertise. This is because, even if all of these has been proved to be valid for a source, there is still the intention aspect of it because historical source is human being which expresses things in an intelligible way that necessitates having intention (purposeful). Thus, what if the source's intention was bad, although their memory was fine? It would turn out to be insufficient to rely upon. This has been noticed by al-Biruni when he said that lies and forgery is the necessary problem in history research that must be solved as best as possible (al-Biruni 1879, 3).

Al-Biruni was a devout Muslim, he defends the Islamic doctrines and traditions (Nasr 1978, 173). If this claim was true, then proving the epistemic justification for moral judgement in 'ulum al-hadith is basically justifying the practice of moral judgement in al-Biruni's historical work. Taking this premise, the arguments therefore can be deduced as follows: (1) al-Biruni research was influenced by Islamic traditions and doctrines; (2) 'ulum al-hadith is the Islamic tradition of preserving history; (3) both al-Biruni in al-Athar al-Baqiyah and 'ulum al-hadith uses moral judgement; (4) therefore, defending 'ulum al-hadith is equivalent with defending al-Biruni's proposition to use moral judgement in history. 'Ulum al-hadith and history is basically the same kettle of fish; it studies past event of human affairs (Brown 2009,259). Only that 'ulum al-hadith is a unique preservation of history and cannot be exactly emulated, because it was a product of historical event; therefore, it is unrepeatable (e.g. its isnad). Nonetheless, its nature of study is the same, it is just difference in wordings (khilaf lafzi), not difference in meaning (khilaf ma'nawi).

'Ulum al-hadith necessitates criticising the moral degrees of hadith reporters (Ahmad Kamil 2016, 45-46). Before going through "why 'ulum al-hadith practices moral criticism or judgement?", the epistemology of testimony must be presented first. This is a huge topic but in order to understand the epistemic justification for al-Biruni's moral judgement, at least some basics of epistemology of testimony must be known. Testimony is an indispensable source of truth. If contemplated, we used testimony all the time in operating our daily life: at the workplace, reading news, learning in school, etc. (Coady 1973, 151-152). It has been argued by many epistemologists that even in science, testimonial evidence is a necessary component to establish scientific theories (Evans 2000, 48). The easy example would be the formation of theory of evolution, which depends upon multiple observations that are unachievable by the capacity of one person. The main question here is "How can we know that the testimonies or observers are speaking the truth? It could be that they are lying?" Well, the acknowledgement of the possibilities of them to lie is the main reason which necessitates moral judgement to be practiced in the first place. The possibility of past informers to lie as the reason for moral judgement 
in history to be practiced also was acknowledged by some western historians. Lord Acton $(1911,42)$, for example, had wrote about this principle.

This is basic reasoning practiced by men, though sometimes unconsciously. For instance, if you sick, would you believe in the medical advice from someone who you knew him to be a liar, or would you take advice from an honest friend of yours who studied medicine? Obviously, you cannot trust yourself on this for you lack the knowledge and the means to know it. Hence, the most reasonable and epistemically-justified thing to do is believing in the say-so of your honest friend. But there is a hidden assumption here, this example assumes that we already know that the former must be lying and the latter was honest. Well, this decision was based upon epistemological probability (Brown 2009, 262; Fricker 2006, 233-234). It is probable that a person, whether he was known to be an honest person or a liar, to lie. But, the default position of perceiving a person to lie and not to lie is fifty-fifty, which is also one meaning of the word zann (probability). However, if evidence were given, it will raise the "epistemic bar" up to $99 \%$ for the person speaking the truth (Hallaq 1999, 82). Therefore, when the epistemic bar of a person to speak the truth exceeds lying, it is rational to believe that he is speaking the truth. Unless someone adopt pure scepticism to run his or her daily life, which eventually leads to being practically inconsistent (Brown 2009, 266; 269-270; Hanaffie 2016, 137-138).

The question now, what is the nature of this evidence? The nature of the evidence or the lie detector, is the moral status of the person. This is because, lying - in general - is considered to be an objectively bad moral conduct. The question of "how" we get to know that it is objectively bad is not the topic of this discussion because it falls under moral epistemology. For the sake of this article, this premise is taken to be true. Therefore, if a person often displayed objectively bad moral behaviour, it logically follows that the person used to commit bad deeds, including lying. This is the path taken in hadith examination (Ahmad Kamil 2016, 92). Therefore, it is reasonable to infer the possibilities of a person to lie or speaking the truth from the moral display of the person. This constitutes the rationale for hadith studies to judge the moral status of its narrators, either by directly witnessing it or by testimonies of other trustable witnesses (Ahmad Kamil 2016, 81-83). In light of this, Mohd Akil et al. $(2015,286)$ writes that Islamic method of moral judgement in history is "not aimed to disfigure or glorify the narrator, but aimed to secure the purity and sanctity...from the craftiness of liars... It is impossible without this science, we can distinct whether authentic, fabricated, or weak". Having established this, taking the premise that al-Biruni practices moral judgement in order to know the truth of his historical sources and the way he does it was influenced by 'ulum al-hadith, his moral judgement in historiography is also justified. 


\section{Conclusion}

Analysing the way al-Biruni gave moral judgements in al-Athar al-Baqiyah, it shows that the discussion of "should or should not historians make moral judgement in history" is not as simple as it sounds. From the perspective of partisan of moral judgement in history, it shows there are various issues, elements and aspects which need to be considered. Al-Biruni's position therefore was not simplifying the permissibility of using moral judgement in history research. It is allowed but under a certain context, limit and scope. This study already explained three forms of moral judgement in history employed by al-Biruni: (1) personal moral judgement in describing historical actor(s), (2) impersonal moral judgement in describing historical actor(s) and (3) moral judgement towards historical sources. Also, presented some of al-Biruni's justifications for it: to assess the trustworthiness of the sources, either the sources contain lies or speaking the truth, or concocted and as a tool to discover biases of a source in conveying historical truth. Moreover, the justification also came from the influence of Islamic doctrines and teachings.

Through the philosophical lenses of other academics, this study concludes that al-Biruni's moral judgement is proper, not a blameworthy one. Under the purpose of truth, accountability and progress as propounded by John Stuart Mill, it proves that al-Biruni exercised his judgement in a controlled manner. Moreover, having justified the epistemic justification of 'ulum al-hadith that practices jarh wa ta 'dil (criticism and praise), al-Biruni was therefore justified in practicing moral judgement in history because he was known to be adhering to the Islamic principles and traditions firmly. In summary, this study concludes that the epistemic justification for al-Biruni to practice moral judgement in history was because it corresponds with the nature of historiography; while the opposite of it was not practical in historiography.

\section{Acknowledgements}

The authors would like to thank Universiti Sains Malaysia for the Short-Term Research Grant (2018-2021) [304/PHUMANITI/6315177] entitled "The Concept of Objectivity in the Philosophy of Islamic Research: A Study on al-Bīrūnī and Șadr ad-Dīn Shīrāzī’s Thoughts" which funded the current research. 


\section{References}

Ahmad Kamil Jamilin. 2016. Ilmu jarh wa ta 'dil: Praktikal dalam kehidupan Muslim dan pendakwah. Paper presented at the Home of Hadith: Cinta Hadith Wasilah Cinta Rasul. Kuala Lumpur, 1 May.

Ahmad, R. 2010. Al-Biruni: A great Muslim scientist, philosopher and historian (9731050 AD). Pakistan Vision 10(1): 167-179.

Al-Biruni, Mohammad Ibn Ahmad. 1910. Al-Biruni's India: An account of the religion, philosophy, literature, geography, chronology, astronomy, customs, laws and astrology of India about A.D. 1030, (Vol. I). Translated by E. Sachau. London: Keagan Paul, Trench, Tubner \& Co. Ltd.

. 1879. The chronology of ancient nations: An English version of the Arabic text of the Athar al-Bakiya of al-Biruni, or "Vestiges of the Past", collected and reduced to writing by the author in A.H. 390-1, A.D. 1000. Translated by E. Sachau. London: WH Allen \& Co.

Ardi, M.N., Fatimah Abdullah and al-Tamimi, Shihab. 2016. Al-Biruni: A Muslim critical thinker. International Journal of Nusantara Islam 4(1): 1-12. https://doi. org/10.15575/ijni.v4i1.490

Atkinson, R.F. 1978. Knowledge and explanation in history: An introduction to the philosophy of history. Basingstoke, UK: Macmillan Education Ltd. https://doi. org/10.1007/978-1-349-15965-9_2

Babbage, S. 1964. The place of moral judgments in the interpretation of history. The Churchman 78: 32-47.

Barton, K.C. 2005. Primary source in history: Breaking through the myths. The Phi Delta Kappan 86(10): 745-753. https://doi.org/10.1177/003172170508601006

Berkhofer, R.F.J. 1995. Beyond the great story: History as text and discourse. Cambridge: The Belknap Press of Harvard University Press.

Boilot, J. 1974. The long odyssey. The UNESCO Courier June: 10-14.

Boucher, D. 1985. Texts in context: Revisionist method for studying the history of ideas. Dordrecht, Netherlands: Martinus Nijhoff Publishers. https://doi.org/10.1007/97894-009-5075-7

Brown, J.A.C. 2009. Did the prophet say it or not? The literal, historical and effective truth of hadiths in early Sunnism. Journal of the American Oriental Society 129(2): 259-285.

Bufano, M. 2008. A reconsideration of the Sunni-Shi'a divide in early Islam. MA diss., Clemson University.

Child, A. 1951. Moral judgement in history. Ethics: An International Journal of Social, Political and Legal Philosophy 61(4): 297-305. https://doi.org/10.1086/290792

Coady, C.A.J. 1973. Testimony and observation. American Philosophical Quarterly 10(2): 149-155.

Collingwood, R.G. 1966. The idea of history. London: Oxford University Press.

Evans, R.J. 2000. In defence of history. London: Granta Books. 
Falola, T. 2011. History in Sub-Saharan Africa. In The Oxford history of historical writing, volume 4: 1800-1945, eds. S. Macintyre, J. Maiguascha and A. Pok, 597-618. Oxford: Oxford University Press. https://doi.org/10.1093/acprof:osobl/ 9780199533091.003 .0030

Fischel, W.J. 1961. Ibn Khaldun's use of historical sources. Studia Islamica 14: 109-119. https://doi.org/10.2307/1595187

Fricker, E. 2006. Testimony and epistemic autonomy. In The epistemology of testimony, eds. J. Lackey and E. Sosa, 225-252. Oxford: Oxford University Press. https://doi.org/10.1093/acprof:oso/9780199276011.003.0011

Gafurov, B. 1974. Abu al-Rayhan Mohammed ibn Ahmed al-Biruni: A universal genius who lived in Central Asia a thousand years ago. The UNESCO Courier June: 4-10.

Hallaq, Wael. 1999. The authenticity of prophetic hadith: A pseudo-problem. Studia Islamica 89: 75-90. https://doi.org/10.2307/1596086

Hanaffie Hasin. 2016. Hadis dhaif dalam fadhail amal, targhib, tarhib dan akhlak: Merungkai khilaf dan kekusutan. Paper presented at the Home of Hadith: Cinta Hadith Wasilah Cinta Rasul. Kuala Lumpur, 1 May.

Hooker, B. 2017. What makes a judgement a moral judgement. Journal of Political Theory and Philosophy 1(1): 97-112.

Ibn Khaldun. 1958. The muqaddimah: An introduction to history. Translated by F. Rosenthal. London: Routledge and Kegan Paul.

Kamar Oniah Kamaruzzaman. 2003. Al-Biruni: Father of comparative religion. Intellectual Discourse 2(2): 113-138.

Kamiar, M. (2009). Brilliant Biruni: A life story of Abu Rayhan Mohammad Ibn Ahmad. Lanham, Maryland: The Scarecrow Press, Inc.

Khan, M.A.R. 1951. On the minor tracts of Abu-Raihan Muhammad Ibn Ahmad al-Beruni. In Al-Biruni commemoration volume, A.H. 362-A.H. 1362, eds. M. Ishaque and S.J.V. Courtois, 171-176. Calcutta: Iran Society.

Khan, M.S. 1976. Al-Biruni and the political history of India. Oriens 25/26(1): 86-115. https://doi.org/10.1163/18778372-02502601007

Kosso, P. 2006. Introduction: An epistemology of archaeology. In Archaeological fantasies: How pseudoarchaeology misrepresents the past and misleads the public, ed. G.G. Fagan. Oxford: Routledge.

Krenkow, F. 1951. Beruni and the MS. Sultan Fatih No. 3386. In Al-Biruni commemoration volume, A.H. 362-A.H. 1362, eds. M. Ishaque and S.J.V. Courtois, 195. Calcutta: Iran Society.

Lord Acton. 1911. A lecture on the study of history. London: McMillan and Co. Limited.

Mill, J.S. 2001. On liberty (1859). Kitchener, Canada: Batoche Books.

Mohd Akil Muhamed Ali, Mohamad Norazan Ibrahim, Abur Hamdi Usman, Mohd Arif Nazri and Muhd Najib Abdul Kadir. 2015. Al-jarh wa ta'dil: Its significant in the science of hadith. Mediterranean Journal of Social Sciences 6(2): 284-292.

Morgan, D.N. and Rasinski, T.V. 2012. The power and potential of primary sources. The Reading Teacher 65(8): 584-594. https://doi.org/10.1002/TRTR.01086

Nasr, Seyyed Hossein. 1978. An introduction to Islamic cosmological doctrines (revised edition). London: Thames and Hudson Ltd. 
1974. Free-wheeling philosopher: Al-Biruni was a model of the thinker who could harmonize various forms of knowledge without becoming a slave to a particular method or school. The UNESCO Courier June: 38-42.

Notzon, B. and Nesom, G. 2005. The Arabic naming system. Science Editor 28(1): 20-21.

Oldfield, A. 1981. Moral judgments in history. History and Theory 20(3): 260-277. https://doi.org/10.2307/2504557

Phillips, P.T. 2019. Truth, morality and meaning in history. Toronto: University of Toronto Press.

Plantinga, A. 1986. Epistemic justification. Nous 20(1): 3-18. https://doi.org/10.2307/ 2215273

Said, Hakim Mohammed. 1974. "Father" of Arabic pharmacy in Medieval Islam. The UNESCO Courier June: 32-37.

Sakmann, P. 1971. The problems of historical method and of philosophy of history in Voltaire (1906). History and Theory 11: 24-59. https://doi.org/10.2307/2504245

Shaw, I.S. 2012. Human rights journalism: Advances in reporting distant humanitarian interventions. New York: Palgrave Macmillan.

Tucker, A., ed. 2009. Introduction. A companion to the philosophy of history and historiography, 1-6. West-Sussex: Blackwell Publishing Ltd.

Vann, R.T. 2004. Historians and moral evaluations. History and Theory 43(4): 3-30. https://doi.org/10.1111/j.1468-2303.2004.00295.x 